\title{
Sightings of southern right whales (Eubalaena australis) in Namibian waters, 1971-1999
}

\author{
J-P. Roux* ${ }^{*}$ P.B. Best ${ }^{+}$AND P.E. STANDER ${ }^{\dagger}$ \\ Contacte-mail: jproux@mfmr.gov.na
}

\begin{abstract}
Southern right whales were originally abundant in Namibian waters in winter and spring. They were either eradicated from the region or driven to extremely low numbers more than a century ago. Since 1971, 36 incidental sightings and three aerial surveys confirm the regular presence of the species within its historical calving range, between June and December. Calving has been recorded in four successive years and at least 10 calves were born in the area between 1996 and 1999, confirming the existence of a small established breeding population. This represents a northward extension of the hitherto known modern regular calving range in the South East Atlantic Ocean by more than $1,000 \mathrm{~km}$.
\end{abstract}

KEYWORDS: SOUTHERN RIGHT WHALE; INCIDENTAL SIGHTINGS; AERIAL SURVEY; DISTRIBUTION; REPRODUCTION

\section{INTRODUCTION}

The southern right whale (Eubalaena australis) was originally widely distributed in all oceans of the Southern Hemisphere between approximately $20^{\circ} \mathrm{S}$ and $55^{\circ} \mathrm{S}$. The main calving areas were concentrated at mid-latitude in coastal waters of South America, southern Africa, southern Australia and New Zealand (IWC, 2001).

In the eastern South Atlantic Ocean, some bays along the southwestern African coastline south of $20^{\circ} \mathrm{S}$ have historically been visited each spring by female right whales to give birth and raise their young, and possibly to mate with accompanying males (Best and Ross, 1986).

Exploitation of southern right whales in the region started during the $18^{\text {th }}$ century. The peak of right whale catches in the area was between 1785 and 1805 (Best, 1981; Best and Ross, 1989; Richards and du Pasquier, 1989; Dekker and de Jong, 1998). Along the Namibian coast (Fig. 1), whalers operated principally from June to September and found right whales inshore, mainly in bays, one near $27^{\circ} 30^{\prime} \mathrm{S}$ (possibly Bakers Bay), Elizabeth Bay, Angra Pequena or Lüderitz Bay, Angra de Conceicao, possibly Spencer Bay (2540'S), Walvis Bay, and several other smaller bays to the north including Angra Fria, and up to Baia dos Tigres in southern Angola (Lacroix, 1968).

By the beginning of the $19^{\text {th }}$ century, catches along the Namibian coast already seemed to be declining (Richards and du Pasquier, 1989). The region of Walvis Bay became a centre for the exploitation of humpback whales (Megaptera novaeangliae) in the mid $19^{\text {th }}$ century and, despite the scarcity of records, it can be assumed that the remaining right whales would also have been targeted during this period. At the time of the beginning of modern whaling, several shore-based whaling stations operated along the Namibian coast between 1912 and 1914, and again between 1923 and 1930, and also along the Angolan coast from 1909 to 1930. Although details of the catch composition are very incomplete, there is no evidence of southern right whales in the catches (with the exception of one right whale taken in southern Angola in 1913), possibly an indication that the

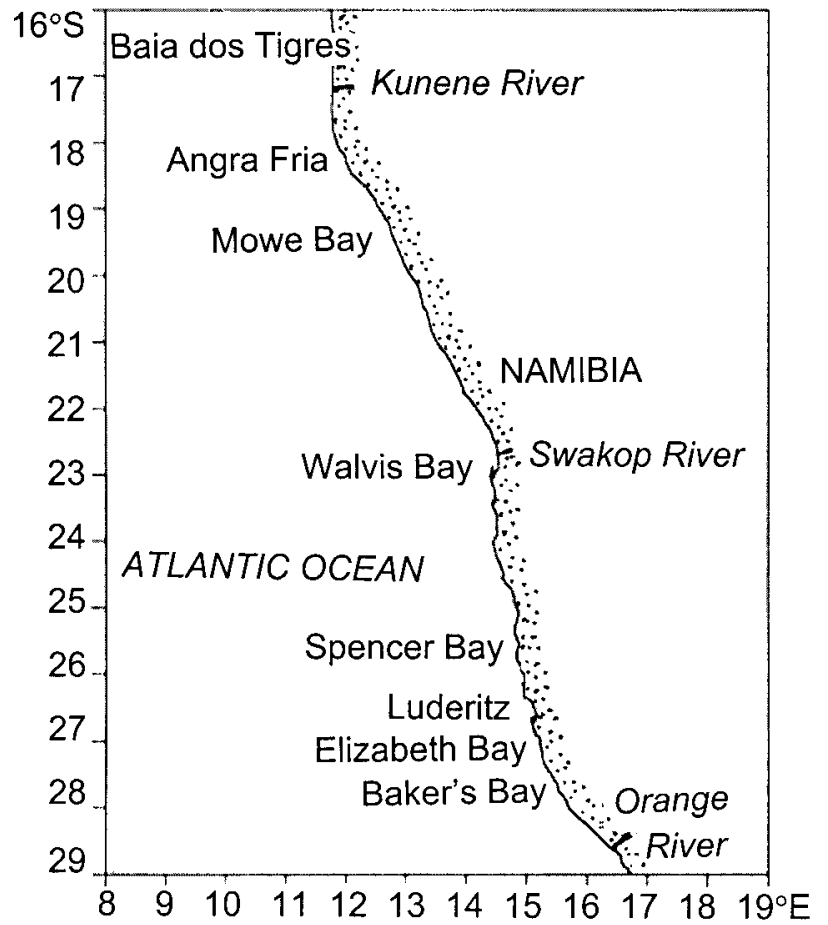

Fig. 1. Map of the Namibian coast.

local breeding population had been eradicated long before the species was granted international protection in 1935 (Best and Ross, 1986; Best, 1994a).

Along the south coast of South Africa, a small remnant population has been reported during the first half of the $20^{\text {th }}$ century and has been increasing since (Best, 1970; 1981; $1990 \mathrm{~b}$ ), but no record of the species in Namibian waters could be found until the early 1970s. Best (1981) reported four confirmed incidental sightings between 1971 and 1981 (including a mother and calf pair) and an additional two sightings (including another mother and calf pair) during an aerial survey in 1978. These were the first indications that

\footnotetext{
*Ministry of Fisheries and Marine Resources, Lüderitz, Marine Research, PO Box 394, Lüderitz, Namibia.

${ }^{+}$Mammal Research Institute, University of Pretoria, c/o South African Museum, PO Box 61, Cape Town 8000, South Africa.

${ }^{\dagger}$ Ministry of Environment and Tourism, Private Bag 13306, Windhoek, Namibia.
} 
breeding adults frequented the area, at least occasionally, since the beginning of the $19^{\text {th }}$ century. However, the take of a 49ft female off Gabon in 1951 as reported by Budker and Collignon (1952), implies that right whales may still have been at least transiting through Namibian waters at this time.

This study reviews recent incidental sightings and the results of aerial surveys along the Namibian coast in order to update the status of the species in the region.

\section{MATERIALS AND METHODS}

Since 1987, skippers and crew of fishing and mining vessels as well as coastal mining contractors have been encouraged to document and report cetacean sightings; species identification guides and reporting forms were distributed. Each report was critically evaluated and classified as doubtful, possible, probable or confirmed according to the experience of the observers, the conditions of the sighting (distance, visibility) and the supporting evidence provided (notes, sketches, photographs and video footage). Sightings were classified as confirmed if they were supported by photographic or video material with some of the species-specific characteristics clearly visible, or if they were made by observers whose experience in identification was known. A sighting was classified as probable if it was reported by an observer whose experience in identification was not known to the authors, provided it was accompanied by detailed notes and/or sketches of body size and colouration, presence of callosities, shape of the flippers and flukes and the absence of a dorsal fin. Animals were termed calves only when observed in close association with an adult and with an estimated size less than half that of the adult. Only the probable and confirmed sightings of southern right whales are discussed here. Other species of baleen whales regularly reported were humpback and minke whales (Balaenoptera acutorostrata) while the bulk of the reports consisted of small odontocetes. When not provided, geographical coordinates of the sightings were estimated from topographical and nautical maps. Only known duplicate sightings were excluded, so it is possible that the data include some sightings of the same individuals on different days.

As most of the Namibian coast is uninhabited and very remote or with restricted access, there is a probable geographical bias in the sighting effort in favour of the few permanent coastal settlements. On the other hand, there appear to be no reasons to suggest a seasonal bias.

In 1998 (29-30 September) and 1999 (7-8 October), aerial surveys were conducted along the coast between the southern Namibian border at the Orange River mouth and the Swakop River mouth. Each survey was divided into two legs, flown on successive days starting in Lüderitz, each leg being flown twice on the same day and returning to Lüderitz in the evening. The northern leg encompassed $512 \mathrm{~km}$ of coastline and the southern leg $310 \mathrm{~km}$. The basic survey methodology followed that of studies of other southern right whale populations in South Africa (Best, 1981), Argentina (Payne et al., 1983) and Australia (Bannister, 1985; 1986). High-winged aeroplanes were used, a Cessna 206 with four observers (including the pilot) in 1998 and a Cessna 172 with two observers (including the pilot) in 1999. The survey track followed the coastline within $1.5 \mathrm{~km}$ offshore and about $500 \mathrm{~m}$ offshore and parallel to the line of breakers. Observers continuously scanned the sea surface on both sides of the aircraft. When searching, the speed of the aircraft was maintained between 182 and $222 \mathrm{~km}$ per hour. The survey altitude was maintained at $1,000 \mathrm{ft}(305 \mathrm{~m})$ except when visibility conditions were not optimal when the altitude was lowered to between 500 and 700ft (152-183m). Areas under coastal fog were not surveyed. When whales were sighted, the aircraft circled the animals at an altitude of $300 \mathrm{ft}(91 \mathrm{~m})$ to confirm identification and determine the position using GPS equipment. Photographs were taken out of an open window with a hand-held $35 \mathrm{~mm}$ camera equipped with a motor-drive and a telephoto lens $(180 \mathrm{~mm} f 2,8)$.

\section{RESULTS}

\section{Incidental sightings}

Out of 36 probable and confirmed incidental sightings recorded in Namibian waters since 1971, 28 have been reported since 1990 (Table 1). This apparent increase in reporting rate can, in great part, be attributed to the large increase in 'observer effort' since the late 1980s and in particular with the development of coastal diamond mining operations in the Lüderitz region. All these sightings were made close to shore (within $3 \mathrm{~km}$ from the coast), probably a reflection of both whale distribution and observer effort.

Right whales have been sighted only during the second half of the year, between the beginning of June and the beginning of December (Fig. 2). The average date of those sightings is 4 September $(\mathrm{SD}=45$ days, $n=36)$. The majority (25 out of 36 ) of the sightings was concentrated in a three-month period (July-September). With the exception of 8 sightings involving between 1 and 3 cow-calf pairs, most sightings were of single animals $(n=19)$ and the rest of pairs of large whales, assumed to be adults $(n=9)$.

The pair of large whales observed in Lüderitz Bay on 1 September 1993 included a male. For more than four hours the whales were observed (with binoculars and spotting scope) from the shore at distances ranging from $50-300 \mathrm{~m}$, involved in what appeared to be mating activity. The two whales remained together, most of the time in body contact, striking the surface repetitively with flukes and flippers. The erect penis of one of them was clearly visible several times.

\section{Survey results}

Table 2 summarises the coverage achieved by the two surveys of 1998 and 1999. Coastal fog is common along the Namib Desert coast and is the cause of the low coverage achieved in 1998. The southern right whale sightings during the surveys are also summarised in Table 2.

\section{Occurrence of calving}

Combining incidental sightings and survey data (Tables 1 and 2), 12 cow-calf pairs have been recorded since 1990. Between 1996 and 1999, mother and calf pairs were sighted every year: 2 in 1996; 4 in 1997; 3 in 1998; and 1 in 1999. From the observed size of the calves (between one third and half the length of the accompanying adult) it was deduced that they were calves-of-the-year. Cow-calf pairs were sighted between mid-July and the beginning of December (Table 1).

Observations at Elizabeth Bay in 1996 provided some details of the residence period of a mother and calf pair. A single adult southern right whale was sighted close to a mining camp within $100 \mathrm{~m}$ from the shore on the southeastern side of Elizabeth Bay on 16 August 1996. Subsequently, this whale was sighted from the same camp virtually on a daily basis. As from the last week of August, it was observed accompanied by a young calf. The birth was 
Table 1

Incidental sightings of southern right whales along the Namibian coast since 1971 . All sightings were made within $3 \mathrm{~km}$ from the coast. Categories of sightings (Cat.) follow the definitions given in the text for 'probable' (P) and 'confirmed' (C).

\begin{tabular}{|c|c|c|c|c|c|}
\hline Date & $\begin{array}{c}\text { No. } \\
\text { whales }\end{array}$ & $\begin{array}{l}\text { No. } \\
\text { calves }\end{array}$ & Source & Cat. & Latitude S \\
\hline 5 Dec. $1971^{1}$ & 1 & 1 & Aerial survey of seal colonies & $\mathrm{C}$ & $28^{\circ} 03^{\prime}$ \\
\hline 15 Oet. $1977^{1}$ & 1 & & Shipboard marine mammal survey & $\mathrm{C}$ & $26^{\circ} 38^{\prime}$ \\
\hline 18 Aug. $1978^{\prime}$ & 1 & & Sketched from shore & $\mathbf{P}$ & $21^{\circ} 08^{\prime}$ \\
\hline 15 Sep $1981^{1}$ & 1 & & Ichaboe Island headman & $\mathbf{P}$ & $26^{\circ} 17^{\prime}$ \\
\hline 12 Sep. 1986 & 1 & & From Shark Island lighthouse & $\mathrm{C}$ & $26^{\circ} 37^{\prime}$ \\
\hline 12 Oct. 1986 & 2 & & Photographed from shore & $\mathrm{C}$ & $26^{\circ} 36^{\prime}$ \\
\hline 8 Jul. 1987 & 2 & & Fishing boat /oddevik - id. as humpback but description right whale & $\mathbf{P}$ & $24^{\prime \prime} 27$ \\
\hline 8 Jul. 1989 & 1 & & Seen at close range from rubber dinghy & $\mathrm{C}$ & $26^{\circ} 37^{\prime}$ \\
\hline 18 Sep. 1990 & 2 & 1 & Seen from aircraft by nature conservator & $\mathbf{P}$ & $23^{\prime \prime} 20^{\prime}$ \\
\hline 9 Sep. 1991 & 1 & & Ichaboe Island headman & $\mathbf{P}$ & $26^{\circ} 17^{\prime}$ \\
\hline 17 Sep. 1992 & 1 & & Possession Island headman & $\mathbf{P}$ & $27^{\circ} 01^{\prime}$ \\
\hline 12 Oct. 1992 & 1. & & Seen breaching from fisheries survey vessel & $\mathbf{P}$ & $17^{\circ} 16^{\prime}$ \\
\hline 1. Sep. 1993 & 2 & & Observed for 4 hours from shore, apparent mating & $\mathrm{C}$ & $26^{\circ} 37^{\prime}$ \\
\hline 26 Jul. 1993 & 2 & 1 & Reported by tugboat captain & $\mathbf{P}$ & $22^{\circ} 53^{\prime}$ \\
\hline 7 Nov. 1993 & 2 & & Seen at close range from diamond mining vessel & $\mathbf{P}$ & $26^{\circ} 49^{\prime}$ \\
\hline 8 Nov. 1993 & 1 & & Observed from shore by nature conservator & $\mathbf{P}$ & $26^{\circ} 44^{\prime}$ \\
\hline 25 Jul. 1994 & 1 & & Seen from fisheries survey vessel & $\mathbf{P}$ & $26^{\circ} 38^{\prime}$ \\
\hline 23 Sep. 1995 & 1 & & Photographed from shore & $\mathrm{C}$ & $27^{\circ} 13^{\prime}$ \\
\hline $10 \mathrm{Jul} .1996$ & 1. & & Seen from diamond mining vessel & $\mathbf{P}$ & $26^{\circ} 51^{\prime}$ \\
\hline $11 \mathrm{Jul} .1996$ & 1 & & Seen from diamond mining vessel & $\mathbf{P}$ & $26^{\circ} 53^{\prime}$ \\
\hline 16 Aug. $1996^{2}$ & 1 & & Observed from mining camp at close range, video taken & $\mathrm{C}$ & $26^{\circ} 57.2^{\prime}$ \\
\hline 25 Sep. $1996^{2}$ & 2 & 1 & Observed from mining camp at close range, video taken & $\mathrm{C}$ & $26^{\circ} 57.2^{\prime}$ \\
\hline 17 Sep. 1996 & 1. & & Photographed at close range from skiboat & $\mathrm{C}$ & $22^{\circ} 33^{\prime}$ \\
\hline 30 Oct. 1996 & 2 & 1 & Observed from shore by nature conservator & $\mathbf{P}$ & $19^{\prime \prime} 22^{\prime}$ \\
\hline 24 Aug. 1997 & 2 & 1 & Seen at close range by Mercury Island headman & $\mathrm{C}$ & $25^{\circ} 43^{\prime}$ \\
\hline 28 Sep. 1997 & 6 & 3 & Seen from aircraft, video taken, Ministry of Environment & $\mathrm{C}$ & $24^{\prime \prime} 46.4^{\prime}$ \\
\hline 15 Jul. 1998 & 2 & 1 & Photographed from survey vessel & $\mathrm{C}$ & $26^{\circ} 36.9^{\prime}$ \\
\hline $16 \mathrm{Jul} .1998$ & 1. & & Seen breaching from diamond mining vessel & $\mathbf{P}$ & $26^{\circ} 42^{\prime}$ \\
\hline $30 \mathrm{Jul} .1998$ & 2 & & Observed by Mereury Island fisheries personnel & $\mathrm{C}$ & $25^{\circ} 43^{\prime}$ \\
\hline 12 Aug. 1998 & 1 & & Seen from diamond mining vessel & $\mathbf{P}$ & $26^{\circ} 52.2^{\prime}$ \\
\hline 14 Aug. 1998 & 1. & & Seen from diamond mining vessel & $\mathbf{P}$ & $26^{\circ} 49^{\prime}$ \\
\hline 6 Oct. 1998 & 2 & & Photographed from diamond mining vessel & $\mathrm{C}$ & $26^{\circ} 44^{\prime}$ \\
\hline 3 Nov. 1998 & 1 & & Seen from diamond mining vessel & $\mathbf{P}$ & $26^{\circ} 46.4^{\circ}$ \\
\hline 2 Jun. 1999 & 1 & & Observed by Jchaboe Island headman & $\mathrm{C}$ & $26^{\circ} 17$ \\
\hline 2 Aug. 1999 & 2 & & Observed by biologist from Mercury Island & $\mathrm{C}$ & $25^{\circ} 43^{\prime}$ \\
\hline 5 Sep. 1999 & 2 & & Video taken from aircraft & $\mathrm{C}$ & $26^{\circ} 26.4^{\prime}$ \\
\hline 14 Nov. 1999 & 2 & & Observed breaching from shore by nature conservator & $\mathbf{P}$ & $19^{\circ} 50.5^{\prime}$ \\
\hline
\end{tabular}

'From Best (1981). ${ }^{2}$ Denotes first and last sightings of the same individual cow, which calved in Elizabeth Bay in August 1996.

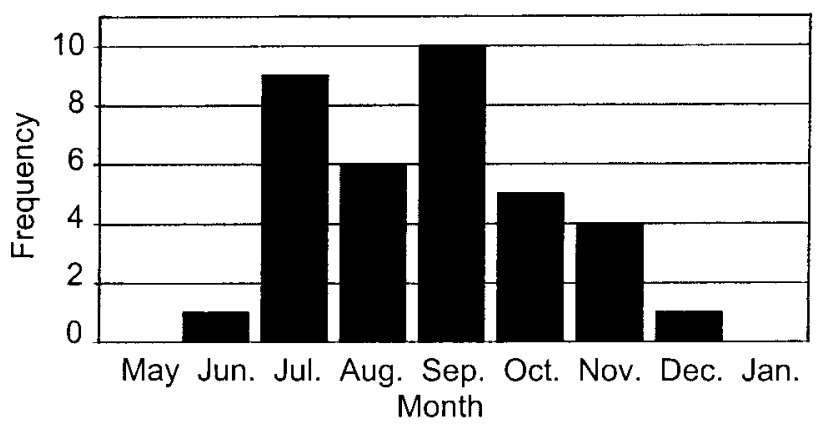

Fig. 2. Seasonality of incidental sightings of southern right whales along the Namibian coast (1971-1999).

not witnessed but is thought to have taken place within two days of 28 August. The mother and calf pair remained in the bay and were seen many times until 25 September. The calf was estimated to be less than one third of the adult's length when first observed and was seen only in close association with the adult. The last recorded sightings of the mother and calf pair were noted on 20, 23 and 25 September. Surveys of the bay by boat on 26 and 27 and along the shore on 28 September failed to locate the whales and they were not sighted again despite continued frequent observations from the shore until mid-November. As only one adult whale was sighted at any time, and because when seen at close range the observers could recognise the pattern of natural markings, it can be assumed that the same adult whale spent the whole period (41 days) inside or in the vicinity of the bay. This whale calved approximately 12 days after arriving and remained in the bay with the young calf for a period of 27 to 31 days after the birth, before departing.

\section{DISCUSSION}

Since 1971, southern right whales have been sighted between the Kunene River mouth on the Angolan border and the vicinity of the Orange River, on the South African border. Some of these whales were mature cows and at least one was a male. At least 10 small calves accompanied by adults were seen along the Namibian coast between 1996 and 1999.

The seasonal distribution of sightings in Namibian waters, from June to December with a peak in September, is supported by the seasonal occurrence of southern right whales in other calving areas in Australia (Bannister, 1986), Patagonia (Payne, 1986) and South Africa (Best and Scott, 1993). The average sighting date was 4 September; whales seem to be present inshore along the Namibian coast slightly earlier in the year on average than at higher latitudes in the 
Table 2

Coverage and sightings of southern right whales during acrial surveys along the Namibian coast.

\begin{tabular}{|c|c|c|c|c|c|c|}
\hline Date & Region & $\begin{array}{c}\text { Coastline } \\
\text { surveyed }(\mathrm{km})\end{array}$ & $\begin{array}{c}\% \\
\text { Coastline }\end{array}$ & No. whales & No. calves & Position \\
\hline \multirow[t]{2}{*}{28 Sep. 1978} & Orange River - & \multirow[t]{2}{*}{810} & \multirow[t]{2}{*}{100} & 1 & 0 & $27^{\circ} 12^{\prime} \mathrm{S}, 15^{\circ} 15^{\circ} \mathrm{E}$ \\
\hline & Walvis Bay & & & 2 & 1 & $24^{\circ} 30^{\prime} \mathrm{S}, 14^{\circ} 35^{\prime} \mathrm{E}$ \\
\hline 29 Scp. 1978 & $\begin{array}{l}\text { Walvis Bay - } \\
\text { Kunene River }\end{array}$ & 660 & 100 & 0 & 0 & \\
\hline \multirow[t]{3}{*}{ 29 Sep. 1998} & I üderitz - & \multirow[t]{2}{*}{310} & \multirow[t]{2}{*}{100} & 2 & 1 & $27^{\circ} 47.94^{\prime} \mathrm{S}$ \\
\hline & Orange River & & & 1 & 0 & $28^{\circ} 16.82^{\prime} \mathrm{S}$ \\
\hline & $\begin{array}{l}\text { Orange River - } \\
\text { I üderitz. }\end{array}$ & 310 & 100 & 2 & 1 & $27^{\circ} 05.68^{\prime} \mathrm{S}$ \\
\hline \multirow[t]{2}{*}{$30 \mathrm{Sep} .1998$} & $\begin{array}{l}\text { I üderitz - } \\
\text { Swakop River }\end{array}$ & 67 & 13 & 0 & 0 & \\
\hline & $\begin{array}{l}\text { Swakop River - } \\
\text { I üderitz. }\end{array}$ & 284 & 55 & 0 & 0 & \\
\hline \multirow[t]{2}{*}{7 Oct. 1999} & $\begin{array}{l}\text { I üderitz - } \\
\text { Swakop River }\end{array}$ & 512 & 100 & 0 & 0 & \\
\hline & $\begin{array}{l}\text { Swakop River - } \\
\text { I üderitz. }\end{array}$ & 390 & 76 & 0 & 0 & \\
\hline \multirow{9}{*}{8 Oct. 1999} & I üderitz - & 310 & 100 & 2 & 1 & $28^{\circ} 31.42^{\prime} \mathrm{S}$ \\
\hline & Orange River & & & 2 & 0 & $28^{\circ} 35.24^{\prime} \mathrm{S}$ \\
\hline & & & & 2 & 0 & $28^{\circ} 35.45^{\prime} \mathrm{S}$ \\
\hline & & & & 3 & 0 & $28^{\circ} 35.59^{\prime} \mathrm{S}$ \\
\hline & \multirow{5}{*}{$\begin{array}{l}\text { Orange River - } \\
\text { I üderitz. }\end{array}$} & \multirow[t]{5}{*}{291} & \multirow[t]{5}{*}{94} & $2 *$ & 0 & $28^{\circ} 35.73^{\prime} \mathrm{S}$ \\
\hline & & & & $2 *$ & 0 & $28^{\circ} 35.45^{\prime} \mathrm{S}$ \\
\hline & & & & $3^{*}$ & 0 & $28^{\circ} 35.31^{\prime} \mathrm{S}$ \\
\hline & & & & 1 & 0 & $28035.19 \mathrm{~S}$ \\
\hline & & & & $2 *$ & $1 *$ & $28^{\circ} 33.07^{\circ} \mathrm{S}$ \\
\hline
\end{tabular}

* Assumed duplicate sightings.

South Atlantic where the peak of abundance inshore is late September (Payne, 1986; Best and Scott, 1993) or early October (Best, 1981).

With the exception of one sighting in early December 1971, cow-calf pairs were sighted between mid-July and the end of October; one calf was born at the end of August in 1996. Despite the small number of observations, this agrees well with the calving season and the residence time of cows and young calves in other calving areas (Whitehead and Payne, 1981; Best, 1994b). Best (1994b) estimated the calving season in South Africa to range from late June to late October with most calves $(95.5 \%)$ born during a period of 118 days around the mean date of birth (24 August). Cow and calf pairs are usually resident in coastal waters of South Africa for about a month before starting their southerly migration (Best and Scott, 1993), but some pairs may stay in the same bay for more than two months (Best, 1981).

Historical records place the northernmost limit of the coastal distribution of the species prior to exploitation in southern Angola, and Baia dos Tigres was a well known whaling ground at the beginning of the exploitation of right whales in the southeastern Atlantic (although it is unclear if calving was taking place there). Best (1981) commented on the striking paucity of modern records for the species north of $32^{\circ} \mathrm{S}$ along the west coast of Southern Africa, and concluded that the species still had to recolonise much of its former range in the region. The analysis of survey data up to 1987 along the coast of South Africa confirmed that the South African population was increasing at a rate close to $7 \%$ per year. However, the bulk of the population is concentrated to the east of the Cape of Good Hope, and only one cow and calf pair and three unaccompanied adults were sighted along the west coast of South Africa north of $32^{\circ} \mathrm{S}$ in four aerial surveys between 1981 and 1986 (Best, 1990b). The sightings presented in this study show that the species has been present throughout its former range in the coastal waters of Namibia in recent years.
The sightings of a single adult off the Kunene River mouth and of a mother and calf pair swimming in a southerly direction on 30 October 1996 at Möwe Bay are particularly significant. They are the northernmost records of the species in Namibia since the end of the whaling era. In addition, considering the date and the swimming direction, the cow and calf pair had presumably started the southward migration. A pair of unidentified whales was sighted the following day from the shore at Terrace Bay, $80 \mathrm{~km}$ south of Möwe Bay, and could have been the same animals (J. and B. Paterson, pers. comm.). Therefore, the calf was probably born earlier in the season and to the north.

Most mature cows calve every $3^{\text {rd }}$ year (Best, 1990a), therefore, sightings of mother and calf pairs during four consecutive years seem to confirm the existence of a small established breeding stock off Namibia. This represents a northward extension of the hitherto known regular modern calving range of the species in the southeastern Atlantic by more than $1,000 \mathrm{~km}$.

No inference can be made on population size and trend from incidental sightings. A minimum of three complete successive aerial surveys of the area would be needed to assess the number of mature females calving in Namibian waters. Further survey data and photo-identification studies are required to estimate the size of the population frequenting the Namibian coast, its trend and its relationship with other sub-populations in the South Atlantic. On the other hand, from the results of the surveys (Table 2), the absence of recorded strandings during the $20^{\text {th }}$ century and the paucity of incidental records, it is clear that the population frequenting the Namibian coast is still very small.

Available whaling records clearly document the extreme depletion of the local stock before the advent of modern whaling (Best and Ross, 1986) and it is possible that the breeding population of Namibia and southern Angola had been almost completely eradicated before any protection 
was granted to the species. In practice, the southern right whale was awarded partial protection only after 1935, and in the South Atlantic some right whales were taken illegally in the Antarctic, Brazil and around Tristan da Cunha until the 1970s (Best, 1981; 1988; Tormosov et al., 1998). The taking of only a few individuals per decade since the beginning of the $20^{\text {th }}$ century could have been sufficient to keep the local population at extremely low levels and to prevent any earlier noticeable recovery.

At least three of the historically important calving bays in Namibia (Walvis Bay, Lüderitz Bay and Elizabeth Bay), have been the sites of important habitat alterations during the $20^{\text {th }}$ century. The first two have been developed into major harbours while a large part of Elizabeth Bay is being filled in by diamond mining operations. Inshore shipping and fishing have increased greatly since the middle of the $20^{\text {th }}$ century and the past two decades have been marked by an accelerated development of coastal and marine mining as well as oil exploration. Anthropogenic factors, through habitat modification and increased mortality risk associated with ship collisions and entanglement in fishing gear (Kraus, 1990), might play a limiting role in the potential recovery of the Namibian right whale population.

\section{ACKNOWLEDGEMENTS}

The two surveys in 1998 and 1999 were financed by the Des and Jen Bartlett Fund. We are grateful to Mr and Mrs Bartlett and the Namibia Nature Foundation (Mrs Judy Storm) for their support. The Ministry of Environment and Tourism and the Namibia Nature Foundation (Save the Rhino Fund) are acknowledged for the use of their aircraft in 1998 and 1999 respectively. Rod Braby was a skilled pilot and observer during the 1999 survey. Pete Bartlett, Helen and Dave Boyer, Nad Brain, Yves Chesselet, Gary Cowan, Etienne Goosen, Tommy Hall, Dirk Heinrich, Joan James, Rian Jones, Frank Jooste, Jessika Kemper, Duane Lackay, Andrew Macun, Bryn Mathias, Heiko Metzger, Gino Noli, Barbara and John Paterson, Johan du Plessis, Frithjof Praetsch, Peter Tarr, Marienne de Villiers, Errol Watt, and skippers and crew of fishing and mining vessels are thanked for recording their observations and incidental sightings, and their help during the surveys. PBB was supported by the National Research Foundation, South Africa.

\section{REFERENCES}

Bannister, J.L. 1985. Southern right (Eubalaena glacialis) and humpback (Megaptera novaeangliae) whales off Western Australia. Some recent aerial survey work. pp. 105-13. In: J.K. Ling and M.M. Bryden (eds.) Studies of Marine Mammals in Southern Latitudes. South Australian Museum, Adelaide. 132pp.
Bannister, J.L. 1986. Southern right whales: status off Australia from twentieth-century 'incidental' sightings and aerial survey. Rep. int. Whal. Commn (special issue) 10:153-8.

Best, P.B. 1970. Exploitation and recovery of right whales Eubalaena australis off the Cape Province. Investl Rep. Div. Sea Fish. S. Afr. 80:1-20.

Best, P.B. 1981. The status of right whales (Eubalaena glacialis) off South Africa, 1969-1979. Investl Rep. Div. Sea Fish. S. Afr. 123:1-44

Best, P.B. 1988. Right whales, Eubalaena australis, at Tristan da Cunha. A clue to the 'non-recovery' of depleted stocks? Biol. Conserv. 46:23-51.

Best, P.B. 1990a. Natural markings and their use in determining calving intervals in right whales off South Africa. S. Afr. J. Zool. 25(2):114-23.

Best, P.B. 1990b. Trends in the inshore right whale population off South Africa, 1969-1987. Mar. Mammal Sci. 6(2):93-108.

Best, P.B. 1994a. A review of the catch statistics for modern whaling in southern Africa, 1908-1930. Rep. int. Whal. Commn 44:467-85.

Best, P.B. 1994b. Seasonality of reproduction and the length of gestation in southern right whales Eubalaena australis. J. Zool., Lond. 232:175-89.

Best, P.B. and Ross, G.J.B. 1986. Catches of right whales from shore-based establishments in southern Africa, 1792-1975. Rep. int. Whal. Commn (special issue) 10:275-89.

Best, P.B. and Ross, G.J.B. 1989. Whales and whaling. pp. 315-38. In: A.I.L. Payne and R.J.M. Crawford (eds.) Oceans of Life off Southern Africa. Vlaeberg, Cape Town. 380pp.

Best, P.B. and Scott, H.A. 1993. The distribution, seasonality and trends in abundance of the southern right whale, Eubalaena australis, off De Hoop nature reserve, South Africa. S. Afr. J. mar. Sci. 13:175-86.

Budker, P. and Collignon, J. 1952. Trois campagnes baleinières au Gabon (1949-1950-1951). Bull. Inst. Étud. Centrafr. 3:75-100. [In French].

Dekker, P. and de Jong, C. 1998. Whaling expeditions of the West India Company to Walvis Bay. Namibia Sci. Soc. 46:47-63.

International Whaling Commission. 2001. Report of the Workshop on the Comprehensive Assessment of Right Whales: A worldwide comparison. J. Cetacean Res. Manage. (special issue) 2:1-60.

Kraus, S.D. 1990. Rates and potential causes of mortality in North Atlantic right whales (Eubalaena glacialis). Mar. Mammal Sci. 6(4):278-91.

Lacroix, L. 1968. Les Derniers Baleiniers Francais. Editions Maritime et d'Outre Mer, Paris. 379pp. [In French].

Payne, R. 1986. Long term behavioral studies of the southern right whale (Eubalaena australis). Rep. int. Whal. Commn (special issue) 10:161-7.

Payne, R., Brazier, O., Dorsey, E.M., Perkins, J.S., Rowntree, V.J. and Titus, A. 1983. External features in southern right whales (Eubalaena australis) and their use in identifying individuals. pp. 371-445. In: R. Payne (ed.) Communication and Behavior of Whales. AAAS Selected Symposia Series 76. Westview Press, Colorado. xii+643pp.

Richards, R. and du Pasquier, T. 1989. Bay whaling off southern Africa, c. 1785-1805. S. Afr. J. mar. Sci. 8:231-50.

Tormosov, D.D., Mikhalev, Y.A., Best, P.B., Zemsky, V.A., Sekiguchi, K. and Brownell Jr, R.L. 1998. Soviet catches of southern right whales, Eubalaena australis, 1951-1971; biological data and conservation implications. Biol. Conserv. 86(2):185-97.

Whitehead, H.P. and Payne, R. 1981. New techniques for assessing populations of right whales without killing them. FAO Fish. Ser. (5) Mammals in the Seas:189-209. 